\title{
Ultimate flexural strength of prestressed concrete beams: validation and model error evaluation
}

\section{Momento último de vigas de concreto protendido: validação e cálculo do erro do modelo}

M. W. MOURA a mwmoura@gmail.com

M. V. REAL a mvrealgm@gmail.com

D. D. LORIGGIO d.loriggio@gmail.com

\begin{abstract}
In this work a computational model is presented to evaluate the ultimate bending moment capacity of the cross section of reinforced and prestressed concrete beams. The computational routines follow the requirements of NBR 6118: 2014. This model is validated by comparing the results obtained with forty-one experimental tests found in the international bibliography. It is shown that the model is very simple, fast and reaches results very close to the experimental ones, with percentage difference of the order of $5 \%$. This tool proved to be a great ally in the structural analysis of reinforced and prestressed concrete elements, besides it is a simplified alternative to obtain the cross section ultimate bending moment.
\end{abstract}

Keywords: reinforced concrete, prestressed concrete, ultimate bending moment, beams.

\section{Resumo}

Neste trabalho é apresentado um modelo computacional que calcula o momento resistente último de seções transversais de vigas de concreto armado e protendido. As rotinas computacionais seguem as prescrições da NBR 6118: 2014. Este modelo é validado através da comparação dos resultados obtidos com quarenta e um ensaios experimentais encontrados na bibliografia internacional. É mostrado que o modelo é bastante simples, rápido e atinge resultados muito próximos dos experimentais, com diferença percentual da ordem de $5 \%$. Esta ferramenta se mostrou uma grande aliada na análise de elementos estruturais de concreto armado e protendido, além de uma alternativa simplificada para obtenção do momento de ruína da seção transversal.

Palavras-chave: concreto armado, concreto protendido, momento resistente último, vigas. 


\section{Introduction}

One of the assumptions of structural analysis is to have at hand a good mathematical model that satisfactorily represents the behavior of the structural element. Thus, in this article, we will present the validation of a mathematical model that calculates the ultimate flexural strength of cross sections of reinforced and prestressed concrete beams.

In this validation, the model results are compared to 41 experimental tests. The determination of the flexural response of the prestressed concrete structures requires initial conditions such as compatibility of deformations, geometric and material properties and equilibrium equations. In this way, it is possible to formulate a mathematical model to obtain the ultimate bending moment $\mathrm{M}_{\mathrm{Rd}}$. The developed model allows the nonlinear analysis of prestressed concrete beams with adherence for two types of cross-section: rectangular and T. An iterative procedure, which uses the secant method, is applied to obtain the depth of the neutral axis, during the process of calculating the bending moment that causes the cross-section failure.

To conclude, it will be shown that this model presents good results and, therefore, can be used as a simple and fast way of calculating the ultimate flexural strength of prestressed concrete beams.

\section{Prestressed concrete beams - ultimate flexural strength evaluation}

Prestressed concrete beams generally exhibit three distinct behavioral phases when subjected to increasing static loads until failure. Figure 1 shows a beam under flexural test and Figure 2 shows the behavior of a prestressed concrete beam with adherent tendons subjected to this test.

\subsection{Stage l: linear elastic}

The linear elastic regime corresponds to the interval between the beginning of the loading and the load that causes the cracking of concrete, $F_{r}$. In this case, the concrete, the non-prestressed steel and the prestressed steel have a linear elastic behavior and the tensile stress in the concrete does not exceeds its tensile strength in bending. Through Figure 3 it is possible to see that all the crosssectional area collaborates in the balancing of the internal forces.

\subsection{Stage II: cracked cross-section}

This stage is achieved after loading on the beam reaching the load

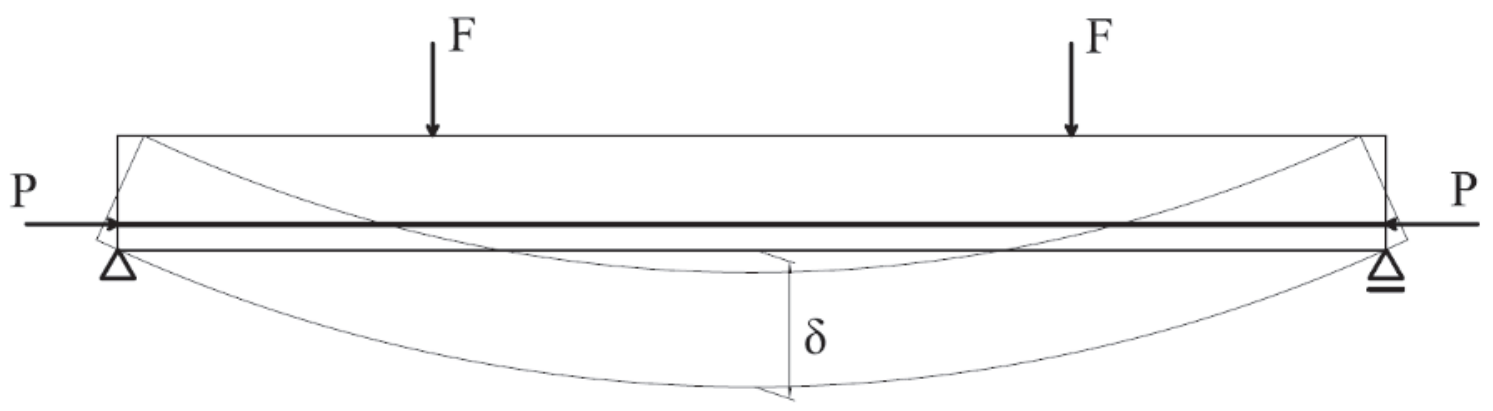

\section{Figure 1}

Flexural test of a prestressed beam

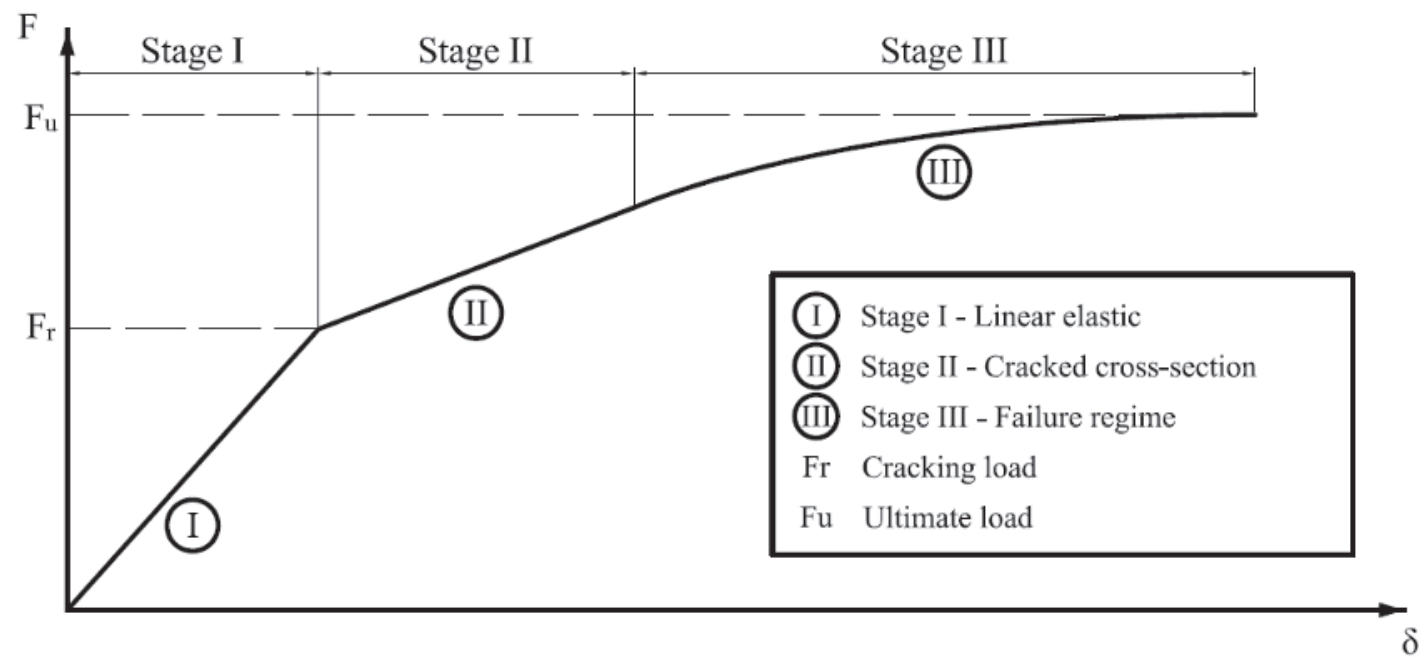

Figure 2

Stages of a beam flexural test (load $x$ deflection) 

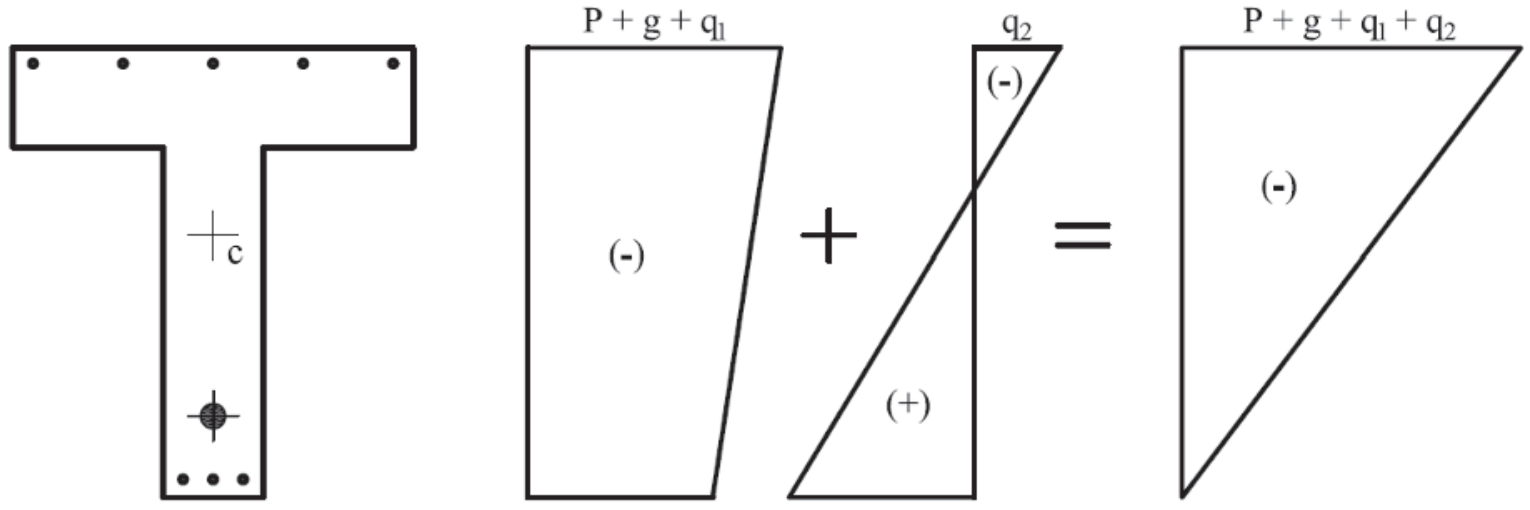

Figure 3

Stresses in the cross-section at Stage I

$\mathrm{F}_{\mathrm{r}}$ that causes cracking. The materials continue to work in the elastic regime, but the tensile stress in the concrete is greater than its tensile strength in the bending and thus only steel is considered to withstand tensile stresses in the member cross-section (Figure 4). The cross-section is cracked.

concrete has tensile stresses greater than the tensile strength of the concrete in bending. It is assumed (Figure 5) that the stress distribution in the concrete occurs according to a parabola-rectangle diagram. Only the compressed concrete zone contributes to resistance to the internal forces.

\subsection{Stage III: failure mode}

\section{Cross-section geometry}

As the load increases, the materials exhibit different behavior from the other phases until failure. The concrete presents non-linear

The developed numerical model applies to rectangular and $T$ cross-sections, for any number of layers of non-prestressed and behavior, the reinforcement reaches the limit of yielding and the prestressed reinforcement. The dimensions of the section are
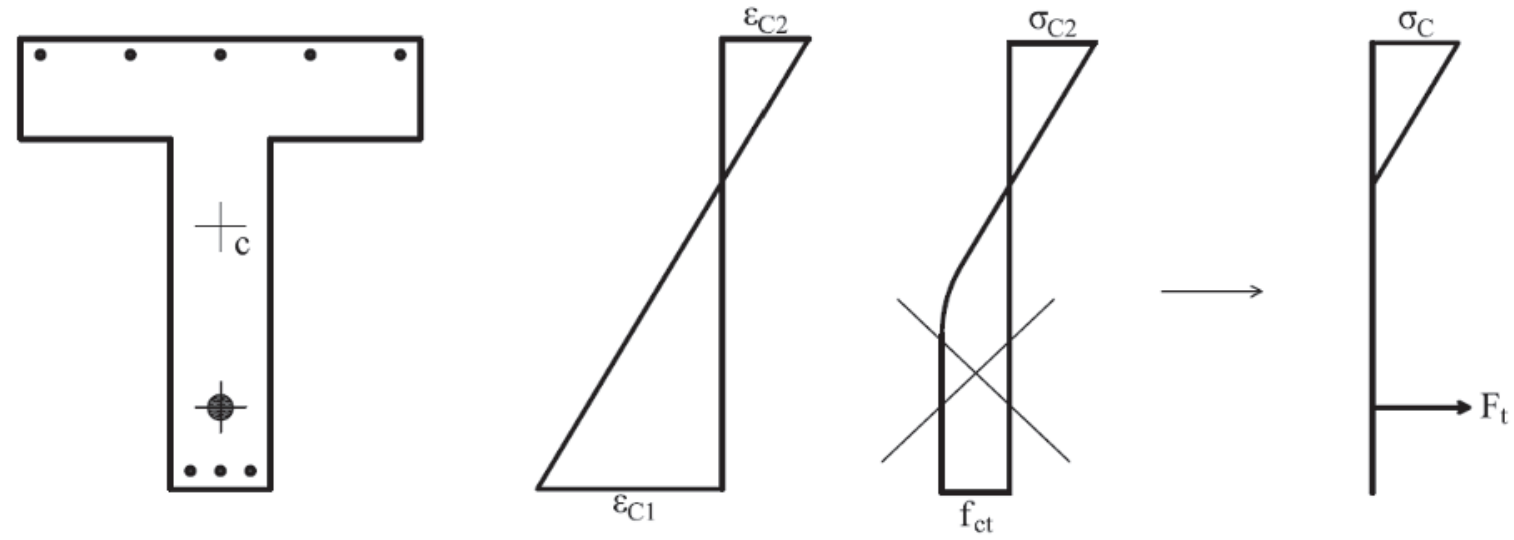

Figure 4

Stresses in the cross-section at Stage II
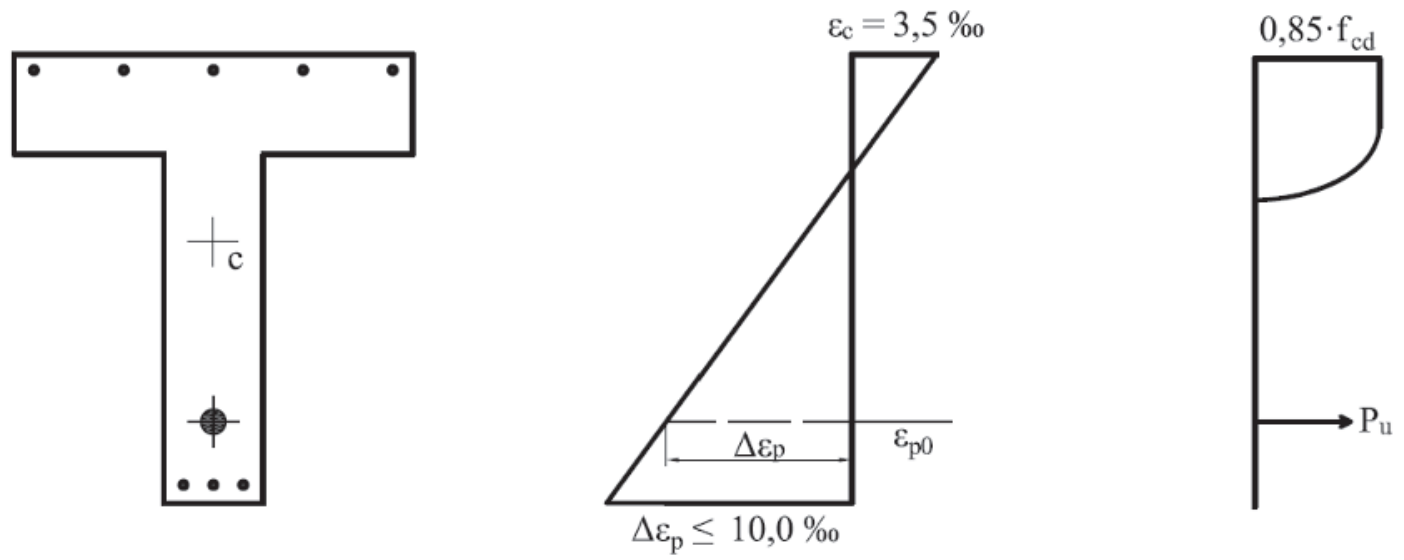

Figure 5

Stresses in the cross-section at Stage III for concrete class up to C50 


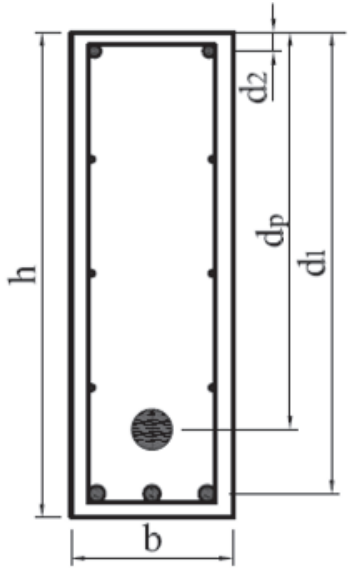

Figure 6

Cross-section geometry and reinforcements

taken as input data of the model. Values referring to web width $\left(b_{w}\right)$, flange width $\left(b_{f}\right)$, total section height $(h)$ and flange height $\left(h_{f}\right)$ should be entered.

Figure 6 and 7 are presented to illustrate the elements that compose the geometry of a typical rectangular and T cross-section, correspondingly. The position and identification of the non-prestressed and prestressed reinforcement are also showed in these figures.

- $b$ is the web width;

- $h$ is the cross-section total height;

- $A_{s 1}$ is the area of non-prestressed tension reinforcement;

$-A_{s 2}$ is the area of non-prestressed compression reinforcement;

- $A_{p}$ is the area of prestressed tension reinforcement;

- $A_{\text {pele }}$ is the area of skin reinforcement;

$-d_{i}$ is the effective depth = distance from extreme-compression fiber to centroid of reinforcement layer " $i$ ".

$-b_{f}$ is the flange width;

$-b_{w}$ is the web width;

- $\mathrm{h}$ is the cross-section total height;

$-h_{f}$ is the flange thickness;

$-d_{i}$ is the effective depth = distance from extreme-compression fiber to centroid of reinforcement layer " $i$ ".

- $A_{s 1}$ is the area of non-prestressed tension reinforcement;

$-A_{s 2}$ is the area of non-prestressed compression reinforcement;
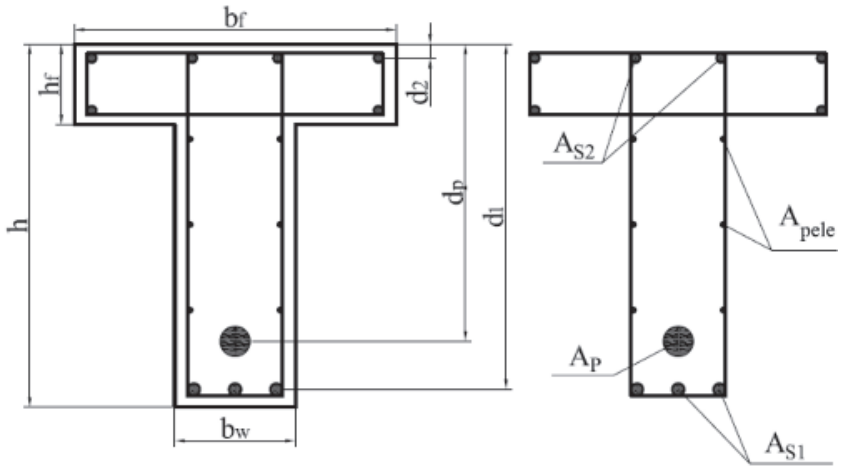

Figure 7

T cross-section geometry and reinforcements

- $A_{p}$ is the area of prestressed tension reinforcement; - $A_{\text {pele }}$ is the area of skin reinforcement.

\section{Fundamental assumptions}

Since the evaluation of the flexural strength of prestressed concrete beams aims to determine the ultimate bending moment $M_{R d}$, for a given cross-section, where the dimensions, reinforcement and material properties are previously known, the analysis is carried out in Stage III. Below are presented the fundamental hypotheses for analysis at such stage.

The cross-sections initially plane and normal to the beam axis remain plane and normal in relation to the deformed axis.

There is perfect adherence between prestressed and non-prestressed reinforcement and the concrete surrounding them.

The strain distribution diagram in the failure regime shall comply with the provisions of NBR-6118:2014, ABNT [3], see Figure 8.

The previous elongation must be included in the deformation of the prestressed reinforcement.

$\varepsilon_{p 0}=\frac{P_{\infty}}{E_{p} \cdot A_{p}}+\frac{\sigma_{c, p}}{E_{c}}$

Where:

$P_{\infty}$ is the prestressing force;

$\mathrm{E}_{\mathrm{p}}$ is the prestressed reinforcement modulus of elasticity;

$\sigma_{(c, p)}$ is the compression stress in the concrete caused by the pre-

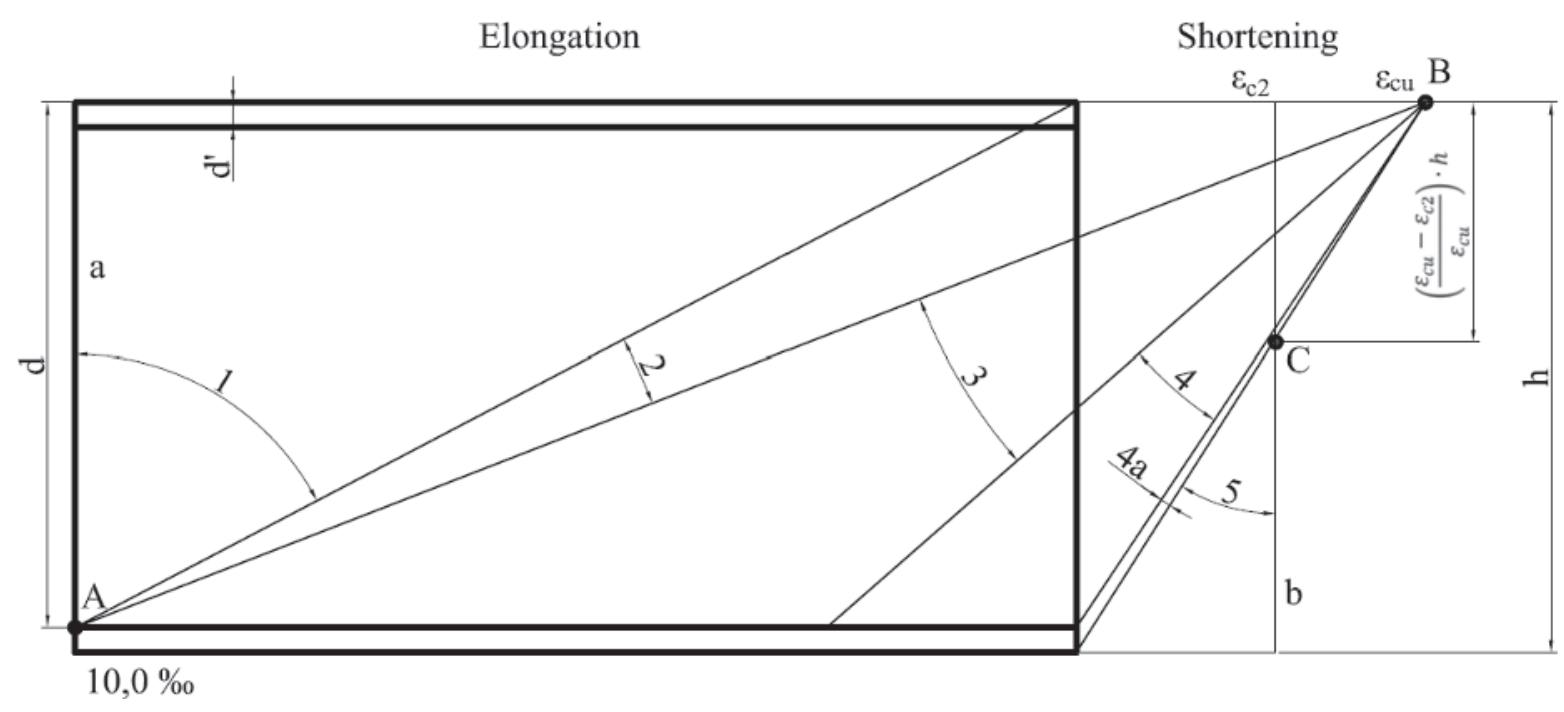

Figure 8

Strain distribution diagram at failure - adapted from NBR-61 18:2014, ABNT [3] 


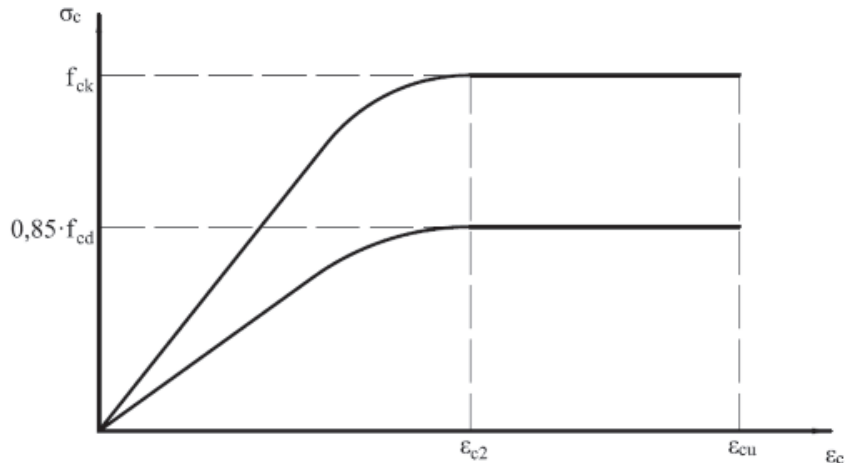

\section{Figure 9}

Stress-strain relationship for concrete in compression

stress at the centroid of the prestressed reinforcement;

$\mathrm{E}_{\mathrm{c}}$ is the concrete modulus of elasticity.

The tensile strength of the concrete is neglected.

For the purposes of simplification, according to NBR-6118: 2014, ABNT [3], a rectangular stress diagram with a depth of $0.8 \cdot x$ for concrete class up to C50 is allowed, where $\mathrm{x}$ is the depth of the neutral axis.Figures 9, 10 and 11 illustrate the constitutive relations, respectively, of the concrete, the non-prestressed reinforcement and the prestressed reinforcement.

In the case of concrete, for analysis in the ultimate limit state, the idealized tensile-strain diagram shown in Figure 9 can be used. The compressive stresses in concrete should obey equation (2).

$\sigma_{c}=0,85 \cdot f_{c d} \cdot\left[1-\left(1-\frac{\varepsilon_{c}}{\varepsilon_{c 2}}\right)^{2}\right]$

For concrete classes up to $\mathrm{C} 50$, the value adopted for the strain of For concrete classes up to $\mathrm{C} 50$, the value adopted for the strain of concrete at the maximum stress is $\varepsilon_{\mathrm{c} 2}=2,0 \%$, and the strain at failure is equal to $\varepsilon_{\text {cu }}=3,5 \%$.

The stress-strain relationship shown in Figure 10 is elastic-perfectly plastic and recommended by NBR-6118:2014, ABNT [3], for calculation in the service and ultimate states. The ultimate strain $\varepsilon_{u}$ applied in this case for passive reinforcement is equal to $10 \%$. For calculations in the service and ultimate limit states, NBR6118:2014, ABNT [3], allows using the simplified bilinear strainstrain relationship according to Figure 11 .

Where:

$f_{\text {pyk }}$ : nominal yielding strength of prestressed steel reinforcement;

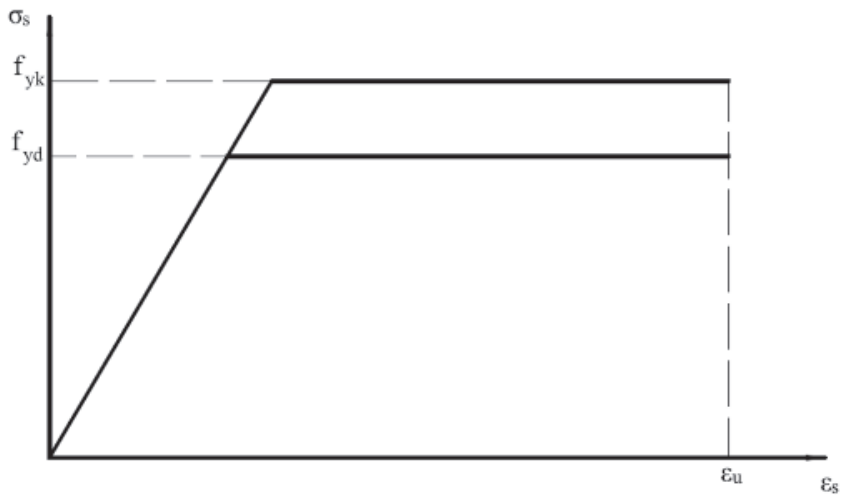

Figure 10

Stress-strain relationship for non-prestressed steel reinforcement

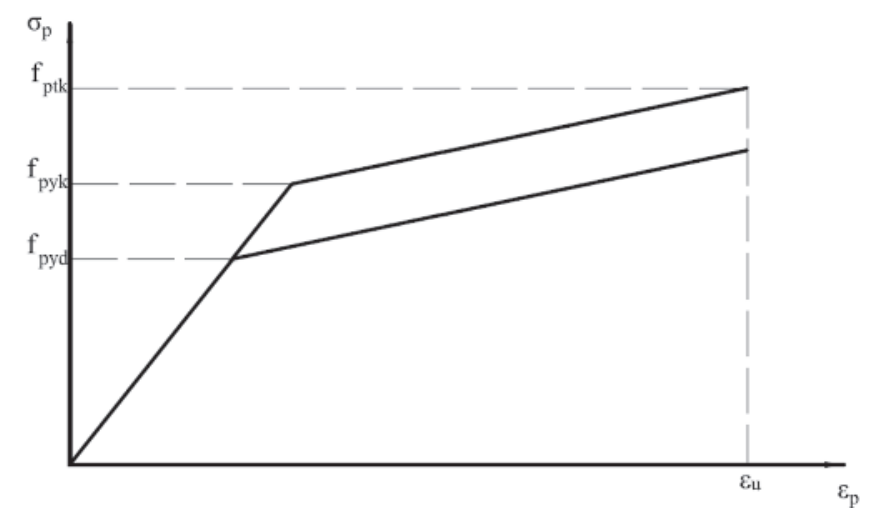

Figure 11

Stress-strain relationship for the prestressed steel reinforcement

$\mathrm{f}_{\text {ptk }}$ : nominal tensile strength of prestressed steel reinforcement; $\varepsilon_{u}$ : strain at failure of prestressed steel reinforcement.

\section{Calculation of the ultimate flexural strength}

The two equilibrium equations required for the calculation of the ultimate bending moment use the basic assumptions and simplifications

\section{Figure 12}
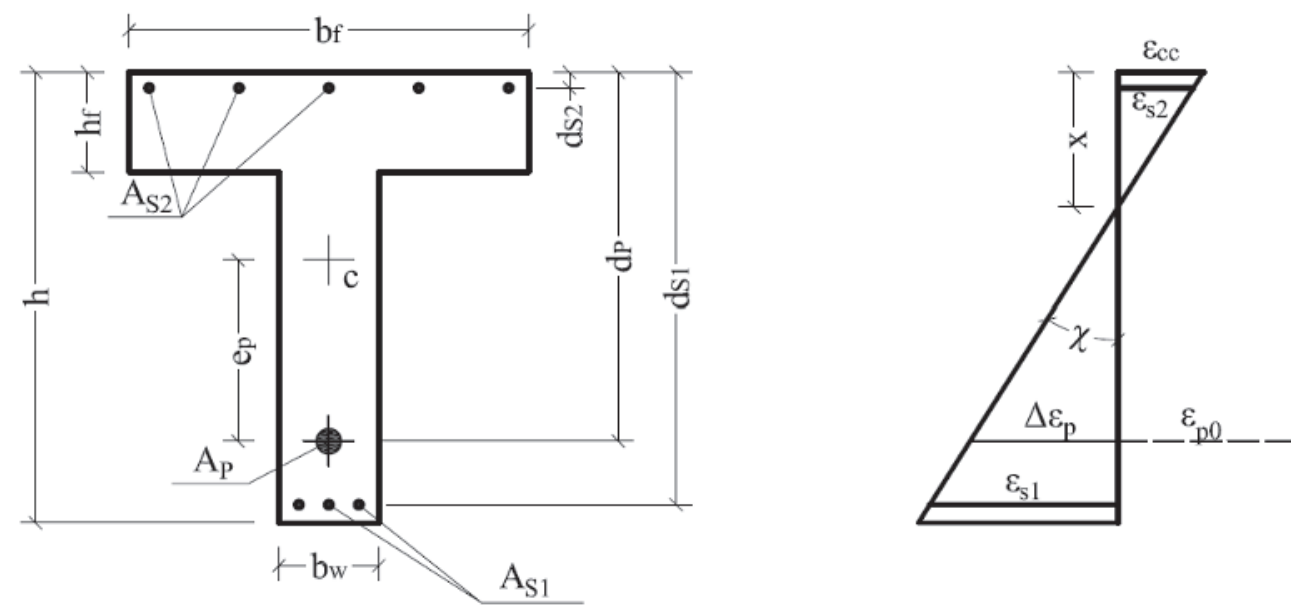

State of strain 

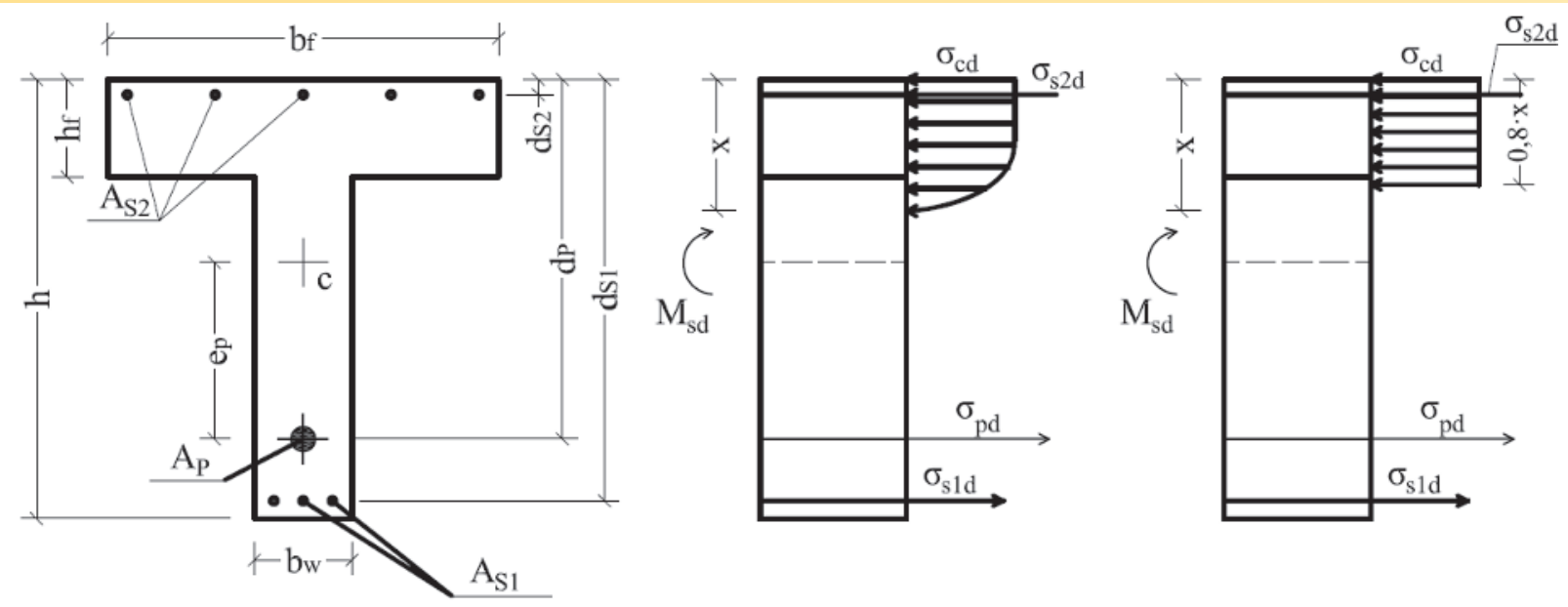

Figure 13

State of stress

allowed in NBR-6118:2014, ABNT [3].

The methodology used allows the computation of the ultimate bending moment for several layers of non-prestressed and prestressed reinforcement, however, since it is a very common case, Figures 12, 13 and 14 show only one layer of non-prestressed tension reinforcement, a layer of non-prestressed compression reinforcement and a prestressed reinforcement layer.

Observing Figures 12, 13 and 14 and assuming that the safety Observing Figures 12, 13 and 14 and assuming that the safety condition, $M_{s d}=M_{r d}$, is satisfied, it becomes possible to make the following considerations.

From Figure 12, the calculation of the strains can be made from:

$\varepsilon_{c c}=\chi \cdot x$

$\varepsilon_{s 2}=\chi \cdot\left(x-d_{s 2}\right)$

$\varepsilon_{s 1}=\chi \cdot\left(d_{s 1}-x\right)$

$\Delta \varepsilon_{p}=\chi \cdot\left(d_{p}-x\right)$

$\varepsilon_{p}=\varepsilon_{p 0}+\Delta \varepsilon_{p}$
(3)

(6) $R_{c d}=\sigma_{c d} \cdot 0,8 \cdot x \cdot b_{f}$

(7) $R_{s 2 d}=\sigma_{s 2 d} \cdot A_{s 2}$
Using the simplification of the rectangular diagram $0,8 \cdot x$ and $\sigma_{c d}=0,85 \cdot f_{c d}$, the resultant forces on concrete and non-prestressed and prestressed reinforcement will be given by:

\section{Figure 14}
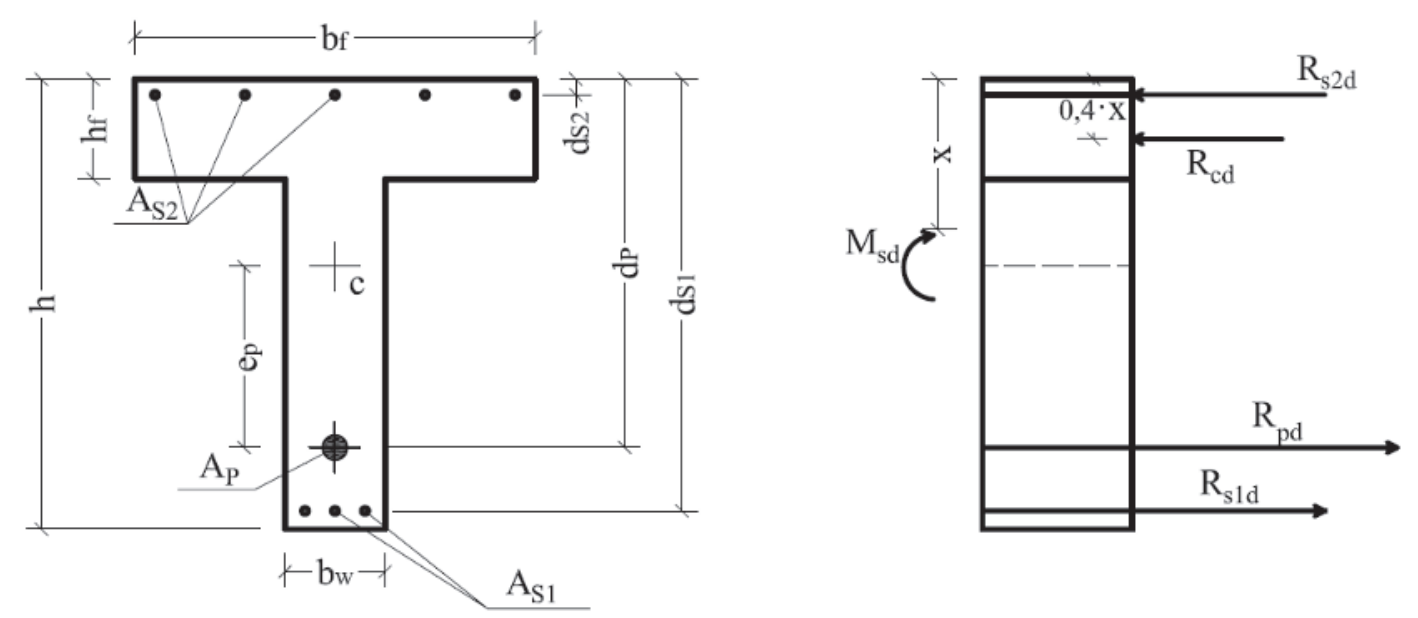

Resultant forces acting on the cross-section 
$R_{s 1 d}=\sigma_{s 1 d} \cdot A_{s 1}$

$R_{p d}=\sigma_{p d} \cdot A_{p}$

In the cross-section, the balance of forces and moments comes In the cross-section, the balance of forces and moments comes from $\sum \mathrm{F}_{\mathrm{h}}=0$ and $\sum \mathrm{M}_{\mathrm{cc}}=0$. The sum of moments will be made around the centroid of the concrete compression zone that is at a distance of $0,4 \times x$ from the compressed edge.

$\sum F_{h}=0 \therefore R_{c d}+R_{s 2 d}-R_{p d}-R_{s 1 d}=0$

$\sum M_{c c}=0 \therefore R_{p d} \cdot\left(d_{p}-0,4 \cdot x\right)+R_{s 1 d}$.

$\left(d_{s 1}-0,4 \cdot x\right)+R_{s 2 d} \cdot\left(0,4 \cdot x-d_{s 2}\right)-M_{R d}=0$

Where $M_{R d}$ is the ultimate bending moment of the cross-section. Expanding equations 17 and 18 in the form of stress and making some simplifications, we have:

$0,8 \cdot \sigma_{c d} \cdot x \cdot b_{f}+\sigma_{s 2 d} \cdot A_{s 2}-\sigma_{p d} \cdot A_{p}-\sigma_{s 1 d} \cdot A_{s 1}=0$

$\sigma_{p d} \cdot A_{p} \cdot\left(d_{p}-0,4 \cdot x\right)+\sigma_{s 1 d} \cdot A_{s 1} \cdot\left(d_{s 1}-0,4 \cdot x\right)$

$+\sigma_{s 2 d} \cdot A_{s 2} \cdot\left(0,4 \cdot x-d_{s 2}\right)-M_{R d}=0$

Equation 19 serves to find the depth of the neutral axis $x$, and consequently, the ultimate bending moment of the section is found in Equation 20. However, the depth of the neutral axis cannot be found directly because the stresses are also functions of $x$. Then, it is necessary to use an iterative numerical process, the secant method, to solve the problem.

Equation 19 can be written generically in the form $\mathrm{f}(\mathrm{x})=0$, where:

$f(x)=0,8 \cdot \sigma_{c d} \cdot b_{f} \cdot x+A_{s 2} \cdot \sigma_{s 2 d}(x)$

$-A_{p} \cdot \sigma_{p d}(x)-A_{s 1} \cdot \sigma_{s 1 d}(x)$

The secant method is an iterative procedure used for the root solution of an Equation (See, for example, ARAÚJO [2]). In this context, the root of Equation 21 should be in the interval $\left[0, d_{s 1}\right]$, which encompasses the domains of deformation for simple bending. The bounds of the range where the root is located are $x_{0}=0$ and $x_{u}=d_{s 1}$. Hence, the function $f(x)$ values at the extremes are $f\left(x_{0}\right)=f_{0}$ and $f\left(x_{u}\right)=f_{u}$, respectively, as shown in Figure 15. As can be seen, the first approximation $x_{1}$ to the root of the function is taken as the intersection of the line through the function ends and the axis of the abscissa.

The value of $x_{1}$ is given by:

$x_{1}=\frac{x_{0} \cdot f_{u}-x_{u} \cdot f_{0}}{f_{u}-f_{0}}$

Then $f_{1}=f\left(x_{1}\right)$ is calculated and the convergence is tested. For the convergence to be satisfied and the solution to the problem to be found, the absolute value of the calculated root must be less than a pre-established tolerance $\left|f_{1}\right|<$ tol. This tolerance, tol, can be as small as you wish.

In case that convergence is not achieved, the evaluation interval should be reduced. For this, it is tested whether the product $\mathrm{f}_{1} \cdot \mathrm{f}_{0}>0$ and if it is true, as shown in Figure 15, the new evaluation interval is $\left[x_{1}, x_{u}\right]$, otherwise $\left[x_{0}, x_{1}\right]$.

With the new interval, smaller than the previous one, the procedure is repeated and a new value of $\mathrm{x}$ is now found, $\mathrm{x}_{2}$, and, again convergence is verified. These steps are repeated until the tolerance reaches the expected value.

Knowing the depth of the neutral axis, we find the ultimate bending moment of the cross-section using Equation 20.

\section{Model validation}

We present below experimental results in the literature for the ultimate bending moment of prestressed concrete beams with initial adherence, denominated here as $\mathrm{M}_{\mathrm{u} \text { exp }}$. Then, the ultimate flexural strength of the beams, called $\mathrm{M}_{\mathrm{u}, \text { calc }}$, is calculated using the numerical model. Thus, it was possible to compare the obtained results and to analyze the limitations of the model.

\subsection{Experimental results}

Forty-one concrete beams with adherent prestressing were

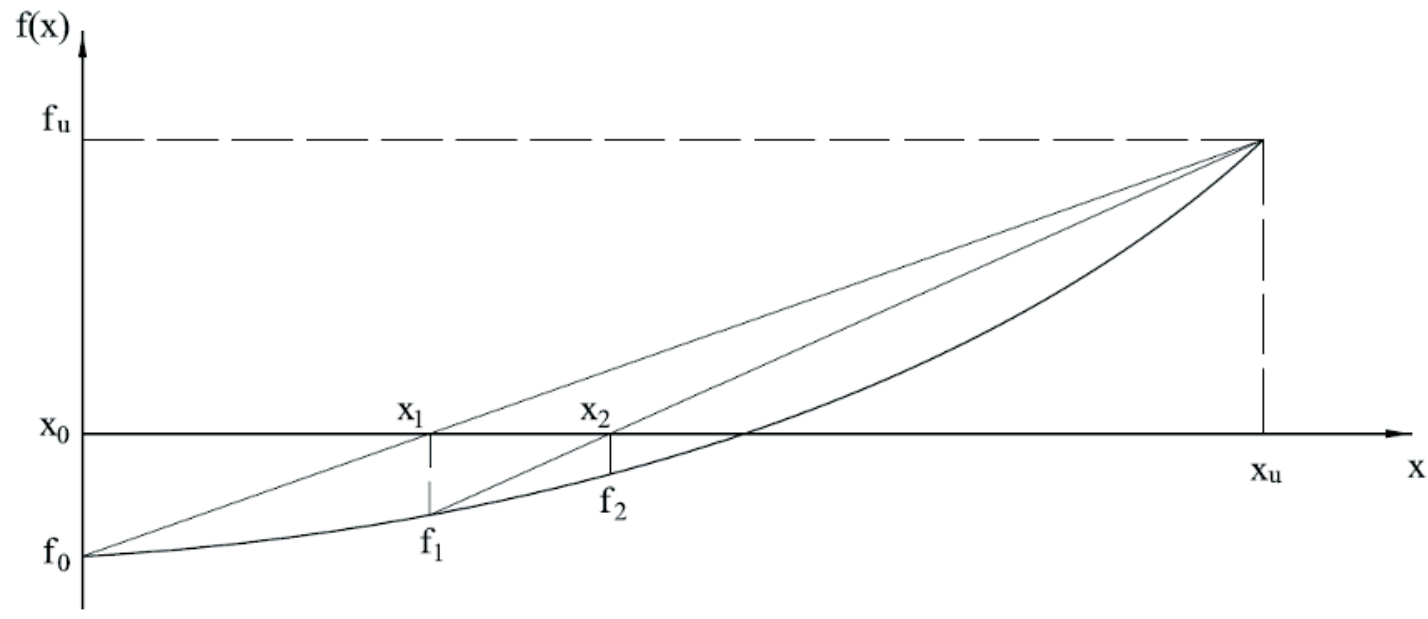

Figure 15

Secant method - adapted from ARAÚJO [2] 
evaluated. They are presented in Table 1 . There are 27 beams of BILLET [4], 6 of FELDMAN [5], 3 of WARWARUK [12], 3 of TAO and DU [11] and 2 of MATTOCK [8] classified according to the author of tests.

$\mathrm{b}:$ is the beam web width;

$b_{f}$ : is the beam flange width;

$\mathrm{h}$ : is the beam height;

$h_{f}:$ is the beam flange height;

$d_{p}$ : is the effective depth of the prestressed reinforcement;

$d_{s}$ : is the effective depth of the non-prestressed reinforcement;

$A_{p}$ : is the prestressed steel reinforcement area;

$A_{s}:$ is the non-prestressed steel reinforcement area;

$\mathrm{f}_{\mathrm{c}}$ : is the mean value of the concrete compressive strength;

$f_{p t}$ : is the mean value of the prestressed steel reinforcement tensile strength; $f_{p y}$ : is the mean value of the prestressed steel reinforcement yielding strenth;

$f_{y}$ : is the mean value of the non-prestressed steel reinforcement yielding strength;

$\mathrm{E}_{\mathrm{p}}$ : is the modulus of elasticity of the prestressed steel reinforcement; $E_{s}$ : is the modulus of elasticity of the non-prestressed steel reinforcement;

$f_{s e}$ : is the effective stress applied to the prestressing tendons.

For the calculation of the pre-elongation of the prestressed reinforcement, it is enough to do:

$\varepsilon_{P 0}=\frac{f_{s e}}{E_{p}}$

The modulus of elasticity $E_{p}$ measured in the tests carried out by BILLET [4] was equal to $20684.27 \mathrm{kN} / \mathrm{cm}^{2}$.

\section{Table 1}

Data from the beams tested by BILLET [4]

\begin{tabular}{|c|c|c|c|c|c|c|c|c|c|}
\hline Beam & $\begin{array}{c}b \\
c m\end{array}$ & $\begin{array}{c}\mathrm{h} \\
\mathrm{cm}\end{array}$ & $\begin{array}{c}d_{p} \\
c m\end{array}$ & $\begin{array}{c}A_{p} \\
c^{2}\end{array}$ & $\begin{array}{c}f_{c} \\
k N / c^{2}\end{array}$ & $\begin{array}{c}f_{\mathrm{pt}} \\
\mathrm{kN} / \mathrm{cm}^{2}\end{array}$ & $\begin{array}{c}f_{p y} \\
k N / / m^{2}\end{array}$ & $\begin{array}{c}f_{\mathrm{se}} \\
\mathrm{kN} / \mathrm{cm}^{2}\end{array}$ & $\begin{array}{c}\mathrm{M}_{\mathrm{u}, \mathrm{exp}} \\
\mathrm{kN} \cdot \mathrm{m}\end{array}$ \\
\hline B1 & 15.24 & 30.48 & 23.14 & 1.497 & 3.79 & 169.34 & 142.03 & 74.33 & 49.975 \\
\hline B2 & 15.62 & 30.86 & 24.21 & 0.748 & 3.74 & 169.27 & 142.03 & 80.53 & 29.679 \\
\hline B3 & 15.24 & 30.78 & 24.43 & 0.374 & 2.59 & 169.34 & 142.03 & 82.74 & 15.361 \\
\hline B4 & 15.49 & 30.71 & 23.34 & 1.497 & 2.37 & 169.34 & 142.03 & 78.53 & 45.162 \\
\hline B5 & 15.49 & 30.63 & 23.70 & 1.606 & 3.90 & 171.68 & 151.55 & 78.67 & 55.602 \\
\hline B6 & 15.39 & 30.63 & 20.62 & 2.206 & 2.03 & 171.68 & 151.55 & 79.98 & 50.938 \\
\hline B7 & 15.57 & 30.81 & 20.55 & 3.013 & 4.07 & 171.68 & 151.55 & 77.77 & 72.943 \\
\hline B8 & 15.57 & 30.63 & 20.29 & 3.013 & 2.26 & 171.68 & 151.55 & 77.84 & 67.167 \\
\hline B9 & 15.39 & 30.63 & 23.44 & 1.510 & 4.36 & 165.47 & 142.51 & 13.72 & 47.725 \\
\hline B10 & 15.39 & 30.56 & 22.89 & 0.381 & 2.43 & 165.47 & 142.65 & 13.10 & 13.314 \\
\hline B11 1 & 15.39 & 30.63 & 23.39 & 1.510 & 2.70 & 165.47 & 142.51 & 14.07 & 47.223 \\
\hline B12 & 15.39 & 30.81 & 21.16 & 2.832 & 3.83 & 165.47 & 142.65 & 14.07 & 62.029 \\
\hline $\mathrm{B} 13$ & 15.29 & 30.73 & 20.70 & 2.077 & 2.59 & 165.47 & 142.51 & 14.62 & 48.023 \\
\hline B14 & 15.24 & 30.68 & 20.29 & 2.832 & 2.59 & 165.47 & 142.51 & 13.93 & 53.094 \\
\hline B15 & 15.32 & 30.71 & 23.60 & 1.510 & 3.94 & 165.47 & 142.65 & 103.42 & 48.308 \\
\hline B16 & 15.27 & 30.51 & 22.86 & 0.381 & 2.30 & 165.47 & 142.65 & 103.63 & 14.141 \\
\hline B17 & 15.24 & 30.51 & 23.09 & 1.510 & 3.16 & 165.47 & 142.65 & 104.11 & 45.894 \\
\hline B18 & 15.24 & 30.38 & 21.06 & 2.077 & 2.83 & 165.47 & 142.51 & 102.59 & 52.172 \\
\hline B19 & 15.44 & 30.66 & 21.01 & 2.832 & 4.29 & 165.47 & 142.65 & 104.32 & 71.560 \\
\hline B20 & 15.37 & 30.81 & 23.55 & 1.006 & 2.63 & 171.68 & 151.55 & 81.77 & 31.753 \\
\hline B21 & 15.44 & 30.66 & 22.99 & 1.006 & 4.52 & 171.68 & 151.55 & 81.36 & 34.397 \\
\hline B22 & 15.42 & 30.66 & 23.19 & 2.006 & 5.26 & 171.68 & 151.55 & 79.43 & 66.937 \\
\hline B23 & 15.34 & 30.56 & 20.83 & 3.013 & 5.65 & 171.68 & 151.55 & 80.88 & 79.980 \\
\hline B24 & 15.42 & 30.58 & 20.93 & 2.406 & 4.22 & 171.68 & 151.55 & 80.25 & 66.964 \\
\hline B25 & 15.39 & 30.58 & 20.35 & 2.006 & 2.25 & 171.68 & 151.55 & 78.94 & 50.165 \\
\hline B26 & 15.49 & 30.40 & 23.55 & 1.606 & 0.88 & 171.68 & 151.55 & 80.32 & 38.993 \\
\hline B27 & 15.42 & 30.66 & 21.23 & 3.013 & 3.16 & 171.68 & 151.55 & 81.36 & 70.136 \\
\hline
\end{tabular}


Table 2

Data of the tests carried out by FELDMAN [5]

\begin{tabular}{|c|c|c|c|c|c|c|c|c|c|}
\hline Beam & $\begin{array}{c}\mathbf{b} \\
\mathbf{c m}\end{array}$ & $\begin{array}{c}\mathbf{h} \\
\mathbf{c m}\end{array}$ & $\begin{array}{c}\mathbf{d}_{\mathbf{p}} \\
\mathbf{c m}\end{array}$ & $\begin{array}{c}\mathbf{A}_{p_{2}} \\
\mathbf{c m}^{2}\end{array}$ & $\begin{array}{c}\mathbf{f}_{\mathbf{c}} \\
\mathbf{k N} / \mathbf{c m}^{2}\end{array}$ & $\begin{array}{c}\mathbf{f}_{\text {pt }} \\
\mathbf{k N} / \mathbf{c m}^{2}\end{array}$ & $\begin{array}{c}\mathbf{f}_{\text {py }} \\
\mathbf{k N} / \mathbf{c m}^{2}\end{array}$ & $\begin{array}{c}\mathbf{f}_{\text {se }} \\
\mathbf{k N} / \mathbf{c m}^{2}\end{array}$ & $\begin{array}{c}\mathbf{M}_{\text {u.exp }} \\
\mathbf{k N} \cdot \mathbf{m}\end{array}$ \\
\hline F28 & 15.62 & 30.56 & 20.14 & 1.494 & 1.72 & 128.24 & 97.91 & 63.78 & 30.70 \\
\hline F29 & 15.65 & 30.58 & 20.50 & 2.615 & 2.95 & 128.24 & 97.91 & 63.91 & 50.63 \\
\hline F30 & 15.47 & 30.73 & 20.52 & 0.561 & 1.99 & 170.99 & 137.90 & 69.71 & 17.64 \\
\hline F31 & 15.44 & 32.26 & 20.90 & 1.868 & 2.38 & 170.99 & 137.90 & 64.88 & 44.93 \\
\hline F32 & 15.24 & 30.81 & 23.67 & 1.839 & 4.95 & 176.51 & 169.61 & 79.50 & 65.31 \\
\hline F33 & 15.32 & 30.66 & 23.06 & 1.103 & 5.74 & 176.85 & 163.41 & 80.60 & 43.36 \\
\hline
\end{tabular}

The modulus of elasticity $E_{p}$ measured in the tests by FELDMAN [5] are presented in table 3.

The modulus of elasticity $E_{p}$ measured in the tests carried out by WARWARUK [12] was equal to $20684.27 \mathrm{kN} / \mathrm{cm}^{2}$.

Table 5: Data of the beams tested by TAO e DU [11]

Table 6: Additional data for the beams tested by TAO e DU [11]

Table 7: Data of the beams tested by MATTOCK [8]

Table 8: Additional data for the beams tested by MATTOCK [8]

Through the developed model, the ultimate bending moment for the forty-one beams was calculated with the purpose of evaluating the ability of the method to determine the flexural strength of the midspan cross-section.

The process is carried out with the aid of spreadsheets that use subroutines created in Visual Basic for Application to calculate the stresses and strains of the element, checking the strain diagram at failure and then obtaining the ultimate bending moment of the cross-section.

Table 3

Modulus of elasticity of the beams tested by FELDMAN [5]

\begin{tabular}{|c|c|}
\hline Beam & $\begin{array}{c}\mathbf{E}_{\mathbf{p}} \\
\mathbf{k N} / \mathbf{c m}^{2}\end{array}$ \\
\hline F28 & 20477.43 \\
\hline F29 & 20477.43 \\
\hline F30 & 19925.85 \\
\hline F31 & 19925.85 \\
\hline F32 & 20408.48 \\
\hline F33 & 20408.48 \\
\hline
\end{tabular}

\section{Table 4}

Data of the beams tested by WARWARUK [12]

\begin{tabular}{|c|c|c|c|c|c|c|c|c|c|}
\hline Beam & $\begin{array}{c}\mathbf{b} \\
\mathbf{c m}\end{array}$ & $\begin{array}{c}\mathbf{h} \\
\mathbf{c m}\end{array}$ & $\begin{array}{c}\mathbf{d}_{\mathrm{p}} \\
\mathbf{c m}\end{array}$ & $\begin{array}{c}\mathbf{A}_{\mathrm{p}} \\
\mathbf{c m}^{2}\end{array}$ & $\begin{array}{c}\mathbf{f}_{\mathbf{c}} \\
\mathbf{k N} / \mathbf{c m}^{2}\end{array}$ & $\begin{array}{c}\mathbf{f}_{\text {pt }} \\
\mathbf{k N} / \mathbf{c m}^{2}\end{array}$ & $\begin{array}{c}\mathbf{f}_{\text {py }} \\
\mathbf{k N} / \mathbf{c m}^{2}\end{array}$ & $\begin{array}{c}\mathbf{f}_{\text {se }} \\
\mathbf{k N} / \mathbf{c m}^{2}\end{array}$ & $\begin{array}{c}\mathbf{M}_{\text {uexp }} \\
\mathbf{k N} \cdot \mathbf{m}\end{array}$ \\
\hline W34 & 16.00 & 30.48 & 23.01 & 1.361 & 2.74 & 184.09 & 151.68 & 78.60 & 40.79 \\
\hline W35 & 15.27 & 30.48 & 23.11 & 0.587 & 3.64 & 184.09 & 151.68 & 81.50 & 22.37 \\
\hline W36 & 15.39 & 30.48 & 23.06 & 2.335 & 3.61 & 184.09 & 151.68 & 76.67 & 64.29 \\
\hline
\end{tabular}

\section{Table 5}

Data of the beams tested by TAO e DU [11]

\begin{tabular}{|c|c|c|c|c|c|c|c|c|c|}
\hline Beam & $\begin{array}{c}\mathbf{b} \\
\mathbf{c m}\end{array}$ & $\begin{array}{c}\mathbf{h} \\
\mathbf{c m}\end{array}$ & $\begin{array}{c}\mathbf{d}_{\mathbf{p}} \\
\mathbf{c m}\end{array}$ & $\begin{array}{c}\mathbf{A}_{\mathrm{p}_{2}} \\
\mathbf{c m}^{2}\end{array}$ & $\begin{array}{c}\mathbf{f}_{c_{c}} \\
\mathbf{k N} / \mathbf{c m}^{2}\end{array}$ & $\begin{array}{c}\mathbf{f}_{\text {pt }} \\
\mathbf{k N} / \mathbf{c m}^{2}\end{array}$ & $\begin{array}{c}\mathbf{f}_{\text {py }} \\
\mathbf{k N} / \mathbf{c m}^{2}\end{array}$ & $\begin{array}{c}\mathbf{f}_{\text {se }} \\
\mathbf{k N} / \mathbf{c m}^{2}\end{array}$ & $\begin{array}{c}\mathbf{M}_{\text {uexp }} \\
\mathbf{k N} \cdot \mathbf{m}\end{array}$ \\
\hline TD37 & 16.00 & 28.00 & 22.00 & 0.588 & 3.56 & 166.00 & 136.00 & 92.40 & 35.00 \\
\hline TD38 & 16.00 & 28.00 & 22.00 & 1.568 & 3.56 & 166.00 & 136.00 & 87.90 & 61.60 \\
\hline TD39 & 16.00 & 28.00 & 22.00 & 1.960 & 3.56 & 166.00 & 136.00 & 82.50 & 71.40 \\
\hline
\end{tabular}


The results are shown in Table 9, where $M_{u, \exp }$ is the ultimate bending moment obtained from the experimental results and $M_{u c a l c}$ is the ultimate bending moment obtained by the numerical model.

To represent the relationship between ultimate bending moments obtained experimentally and those obtained through the model, the Greek letter $\eta$ is used.

By analyzing the forty-one results of the relation between the experimental ultimate bending moment and those of the model all together, it can be verified that the ratio $\eta$ presented a mean value equal to 1.0524 and a standard deviation equal to 0.0963 .
Figure 16 shows the histogram obtained for the forty-one analyzed beams and Figure 17 shows the graph of adherence of the $\eta$ ratio to the normal distribution of probabilities. By subjecting the values of $\eta$ to the Kolmogorov-Smirnov test, ANG and TANG [1], adherence to the Gaussian theoretical model can be demonstrated, since the maximum distance between the values of cumulative probability distribution of the data and the normal curve was below the limit considering a level of significance of $95 \%$. It is possible to note a relative symmetry of the results around the mean, presenting values both below and above. This indicates a non-biased model.

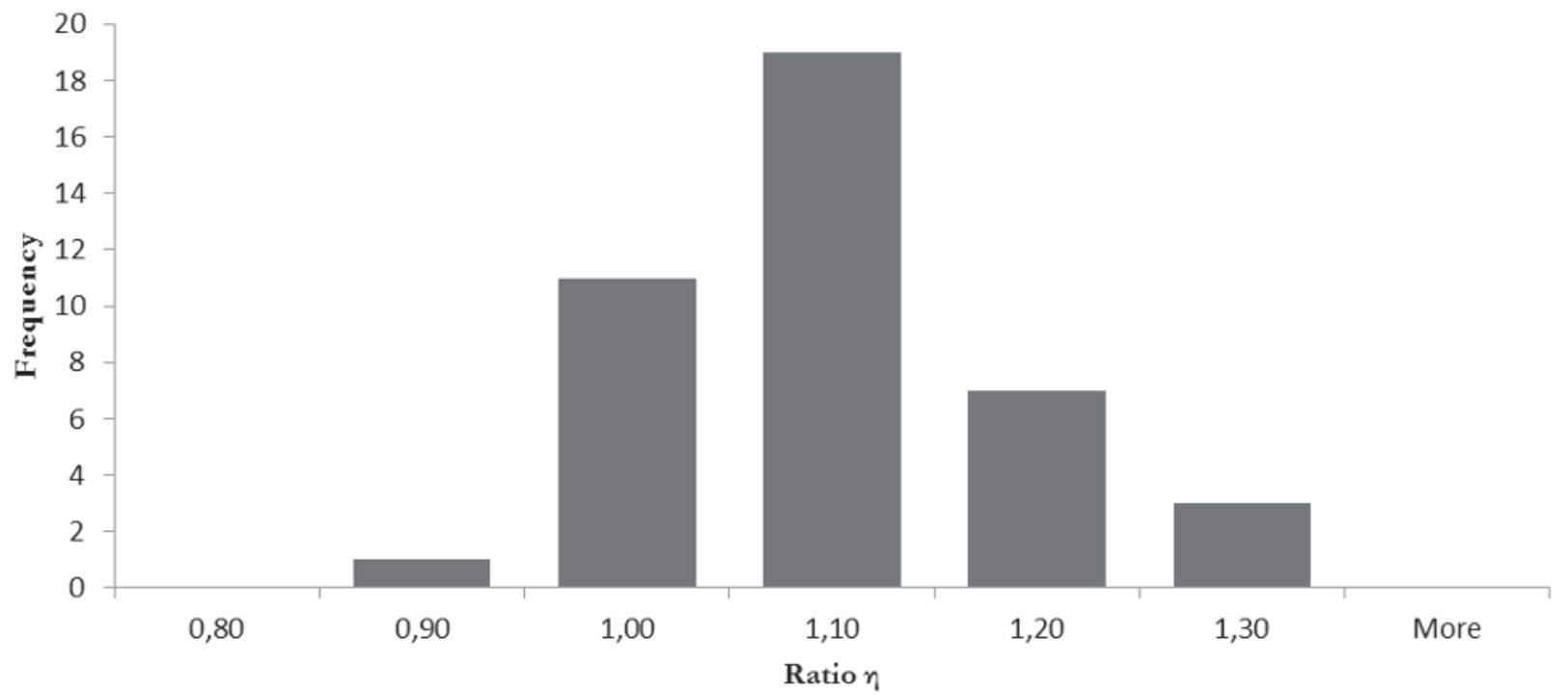

Figure 16

Ratio $\eta$ histogram

Table 6

Additional data for the beams tested by TAO e DU [11]

\begin{tabular}{|c|c|c|c|c|c|}
\hline Beam & $\begin{array}{c}\mathbf{E}_{\mathbf{p}_{\mathbf{p}}} \\
\mathbf{k N} / \mathbf{c m}^{2}\end{array}$ & $\begin{array}{c}\mathbf{E}_{\mathbf{s}} \\
\mathbf{k N} / \mathbf{c m}^{2}\end{array}$ & $\begin{array}{c}\mathbf{f}_{\mathbf{y}} \\
\mathbf{k N} / \mathbf{c m}^{2}\end{array}$ & $\begin{array}{c}\mathbf{A}_{\mathbf{s}_{\mathbf{s}}} \\
\mathbf{c m}^{2}\end{array}$ & $\begin{array}{c}\mathbf{d}_{\mathbf{s}^{2}} \\
\mathbf{c m}^{2}\end{array}$ \\
\hline TD37 & 20000.00 & 20000.00 & 26.70 & 1.57 & 25.00 \\
\hline TD38 & 20000.00 & 20000.00 & 26.70 & 2.36 & 25.00 \\
\hline TD39 & 20000.00 & 20000.00 & 26.70 & 1.00 & 25.00 \\
\hline
\end{tabular}

Table 7

Data of the beams tested by MATTOCK [8]

\begin{tabular}{|c|c|c|c|c|c|c|c|c|c|}
\hline Beam & $\begin{array}{c}\mathbf{b} \\
\mathbf{c m}\end{array}$ & $\begin{array}{c}\mathbf{h} \\
\mathbf{c m}\end{array}$ & $\begin{array}{c}\mathbf{d}_{\mathbf{p}} \\
\mathbf{c m}\end{array}$ & $\begin{array}{c}\mathbf{A}_{\mathbf{p}^{2}} \\
\mathbf{c m}^{2}\end{array}$ & $\begin{array}{c}\mathbf{f}_{\mathbf{c}} \\
\mathbf{k N} / \mathbf{c m}^{2}\end{array}$ & $\begin{array}{c}\mathbf{f}_{\mathbf{p}_{\text {pt }}} \\
\mathbf{k N} / \mathbf{c m}^{2}\end{array}$ & $\begin{array}{c}\mathbf{f}_{\mathbf{f}_{\text {py }}} \\
\mathbf{k} / \mathbf{c m}^{2}\end{array}$ & $\begin{array}{c}\mathbf{f}_{\text {se }} \\
\mathbf{k N} / \mathbf{c m}^{2}\end{array}$ & $\begin{array}{c}\mathbf{M}_{\text {u,exp }} \\
\mathbf{k N} \cdot \mathbf{m}\end{array}$ \\
\hline M40 & 15.24 & 30.48 & 25.40 & 2.534 & 2.76 & 192.36 & 175.89 & 129.76 & 93.44 \\
\hline M41 & 15.24 & 30.48 & 25.40 & 2.534 & 2.76 & 192.36 & 175.89 & 125.90 & 103.44 \\
\hline
\end{tabular}

Table 8

Additional data for the beams tested by MATTOCK [8]

\begin{tabular}{|c|c|c|c|c|c|c|c|}
\hline Beam & $\begin{array}{c}E_{\mathrm{p}} \\
\mathrm{kN} / \mathrm{cm}^{2}\end{array}$ & $\begin{array}{c}\mathrm{E}_{\mathrm{s}} \\
\mathrm{kN} / \mathrm{cm}^{2}\end{array}$ & $\mathrm{kN} / \mathrm{cm}^{2}$ & $\begin{array}{c}A_{s} \\
c^{2}\end{array}$ & $\begin{array}{c}\mathrm{d}_{\mathrm{s}} \\
\mathrm{cm}\end{array}$ & $\begin{array}{l}b_{f} \\
c m\end{array}$ & $\begin{array}{c}\mathrm{h}_{\mathrm{f}} \\
\mathrm{cm}\end{array}$ \\
\hline \multirow{2}{*}{ M40 } & \multirow{2}{*}{19500.00} & \multirow{2}{*}{21000.00} & \multirow{2}{*}{37.71} & Sup. 0.62 & 1.91 & \multirow{2}{*}{-} & \multirow{2}{*}{-} \\
\hline & & & & Inf. 0.62 & 28.58 & & \\
\hline \multirow{2}{*}{ M41 } & \multirow{2}{*}{19500.00} & \multirow{2}{*}{21000.00} & \multirow{2}{*}{37.71} & Sup. 0.62 & 1.91 & \multirow{2}{*}{96.52} & \multirow{2}{*}{5.08} \\
\hline & & & & Inf. 0.62 & 28.58 & & \\
\hline
\end{tabular}




\subsection{Model error evaluation ( $\theta$ )}

In addition to the inherent variability of the strength of the materials and the forces applied to the structures, the uncertainties inherent to the numerical models adopted in the analysis must be considered. The estimation of the model error followed the recommenda- tions presented by MAGALHÃES [6] and MAGALHÃES et al [7].

The relationship between the experimental and theoretical results is affected by variations provided by the computational model, by the variability of the random variables of the system and by the inherent variability of the experimental process of the test, and is represented by Equation 24.

\section{Adherence test}

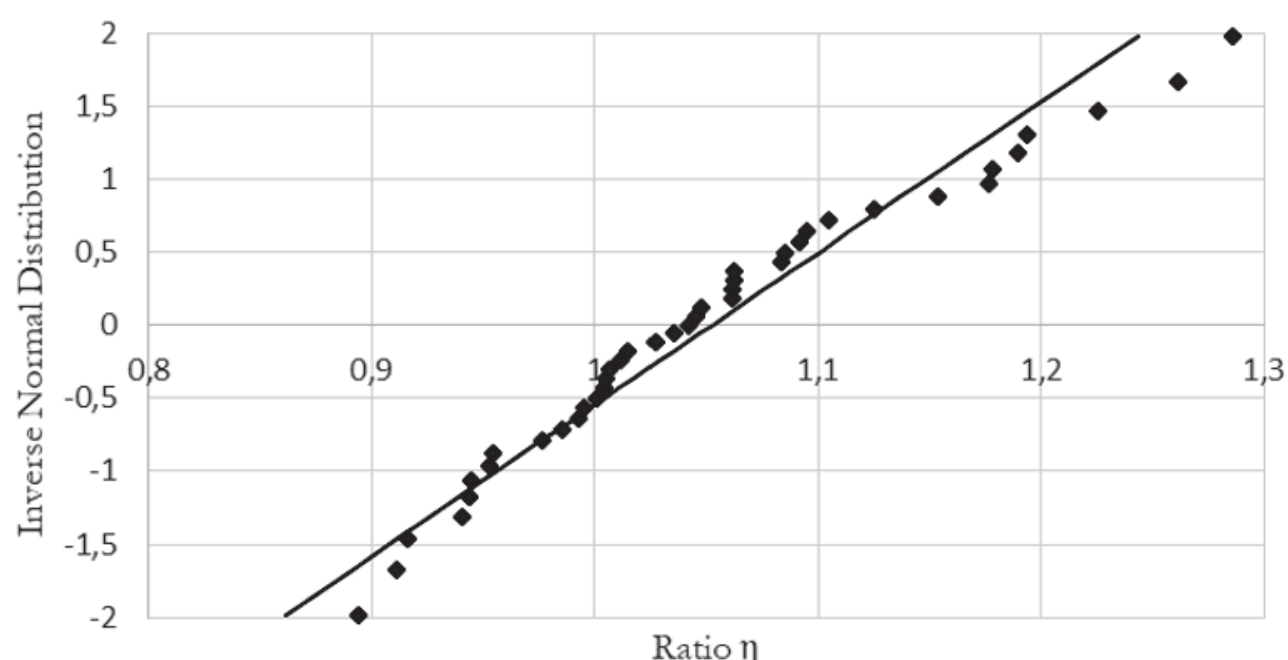

Figure 17

Adherence to Gauss distribution theoretical model

Table 9

Experimental results versus numerical results

\begin{tabular}{|c|c|c|c|c|c|c|c|}
\hline Beam & $\begin{array}{c}\mathrm{M}_{\mathrm{u}, \exp } \\
{[\mathrm{kN} \cdot \mathrm{m}]}\end{array}$ & $\begin{array}{c}M_{\mathrm{u}, \text { calc }} \\
{[\mathrm{kN} \cdot \mathrm{m}]}\end{array}$ & $\frac{M_{u \text { exp }}}{M_{u, \text { calc }}}$ & Beam & $\begin{array}{c}M_{\mathrm{u}, \mathrm{exp}} \\
{[\mathrm{kN} \cdot \mathrm{m}]}\end{array}$ & $\begin{array}{c}\mathbf{M}_{\mathrm{u} \text {,calc }} \\
{[\mathrm{kN} \cdot \mathrm{m}]}\end{array}$ & $\frac{M_{\mathrm{uexp}}}{\mathrm{M}_{\mathrm{u}, \text { calc }}}$ \\
\hline B1 & 49.975 & 46.049 & 1.085 & B22 & 66.937 & 65.933 & 1.015 \\
\hline B2 & 29.679 & 25.226 & 1.177 & B23 & 79.980 & 83.915 & 0.953 \\
\hline B3 & 15.361 & 12.872 & 1.193 & B24 & 66.964 & 66.650 & 1.005 \\
\hline B4 & 45.162 & 43.951 & 1.028 & B25 & 50.165 & 47.249 & 1.062 \\
\hline B5 & 55.602 & 53.684 & 1.036 & B26 & 38.993 & 30.326 & 1.286 \\
\hline B6 & 50.938 & 47.026 & 1.083 & B27 & 70.136 & 73.456 & 0.955 \\
\hline B7 & 72.943 & 77.557 & 0.941 & F28 & 30.70 & 26.056 & 1.178 \\
\hline B8 & 67.167 & 54.800 & 1.226 & F29 & 50.63 & 46.377 & 1.092 \\
\hline B9 & 47.725 & 47.467 & 1.005 & F30 & 17.64 & 15.678 & 1.125 \\
\hline B10 & 13.314 & 12.157 & 1.095 & F31 & 44.93 & 45.150 & 0.995 \\
\hline B11 & 47.223 & 45.071 & 1.048 & F32 & 65.31 & 69.177 & 0.944 \\
\hline $\mathrm{B} 12$ & 62.029 & 67.702 & 0.916 & F33 & 43.36 & 41.489 & 1.045 \\
\hline $\mathrm{B} 13$ & 48.023 & 45.198 & 1.063 & W34 & 40.79 & 44.74 & 0.912 \\
\hline B14 & 53.094 & 48.060 & 1.105 & W35 & 22.37 & 21.060 & 1.062 \\
\hline B15 & 48.308 & 47.966 & 1.007 & W36 & 64.29 & 71.916 & 0.894 \\
\hline B16 & 14.141 & 12.260 & 1.153 & TD37 & 35.00 & 27.744 & 1.262 \\
\hline B17 & 45.894 & 45.833 & 1.001 & TD38 & 61.60 & 58.039 & 1.061 \\
\hline B18 & 52.172 & 52.538 & 0.993 & TD39 & 71.40 & 60.004 & 1.190 \\
\hline B19 & 71.560 & 73.274 & 0.977 & M40 & 93.44 & 94.840 & 0.985 \\
\hline B20 & 31.753 & 33.621 & 0.944 & M41 & 109.93 & 105.484 & 1.042 \\
\hline B21 & 34.397 & 34.005 & 1.012 & - & - & - & - \\
\hline
\end{tabular}


$V_{\eta}^{2}=V_{\text {model }}^{2}+V_{\text {batch }}^{2}+V_{\text {test }}^{2}$

Onde:

$\vee \eta$ é o coeficiente de variação da razão $\eta$;

$V_{\text {model }}$ is the model error coefficient of variation;

$\mathrm{V}_{\text {batch }}$ is the coefficient of variation of the laboratory test results of the system variables, such as dimensions and resistances;

$V_{\text {test }}$ is the coefficient of variation of the results obtained experimentally in the test of the prestressed concrete beams.

$V_{\text {model }}=\sqrt{V_{\eta}{ }^{2}-V_{\text {batch }}{ }^{2}-V_{\text {test }}^{2}}$

The coefficient of variation of the ratio $\eta$ was determined through the 41 experimental results $\left(V_{\eta}=\frac{\sigma_{\eta}}{\mu_{\eta}}=0.091\right)$. The coefficient of variation of the test must be equal to or less than 0.04, MAGALHÃES [6]. The maximum value was used: $\mathrm{V}_{\text {test }}=0.04$.

The batch coefficient of variation was adopted, according to MAGALHÃES [6], as being equal to $0.044\left(\mathrm{~V}_{\text {batch }}=0.044\right)$.

In these conditions, using Equation 25, the value $V_{\text {model }}=0.068$ was calculated.

In general, the model error has a mean value close to 1.00 and a standard deviation between zero and 0.10 , depending on the accuracy of the numerical model.

The mean value of the model error can be evaluated through Equation 26.

$\mu_{\eta}=\mu_{\text {model }} \cdot \mu_{\text {batch }} \cdot \mu_{\text {test }}$

As the batch mean value and the test mean value are close to the unit, the mean value of the model error can be calculated through Equation 27.

$\mu_{\text {model }}=\frac{\mu_{\eta}}{\mu_{\text {batch }} \cdot \mu_{\text {etest }}}=1.052$

According to NOWAK [9], the model error follows a Normal probability distribution, with a mean value between 1.04 and 1.06 for prestressed concrete beams.

Using the model error coefficient of variation $\left(\mathrm{V}_{\text {model }}=0.068\right)$ and the error model mean value $\left(\mu_{\text {model }}=1.052\right)$, the results for the ultimate flexural strength of the beam can be corrected by the model error estimate $\left(\theta_{R}\right)$ randomly generated in each simulation, according to Equation 28. The corrected values of the ultimate bending moment are used in the reliability analysis.

$M_{u, \text { corr }}=\theta_{R} \cdot M_{u, \bmod }$

\section{Results and discussion}

The methodology used to evaluate the ultimate bending moment of prestressed concrete beams is the traditional model that calculates the ultimate flexural strength of the cross-section based on the assumptions of the plane sections and perfect adherence between steel and concrete. In addition the following premises were also considered: the ultimate strain distribution diagram according to NBR-6118:2014, a rectangular stress diagram for concrete, an elastic-perfectly plastic tension diagram for non-prestressed re- inforcement steel and a bi-linear stress diagram for prestressed reinforcement steel. The secant method is employed to solve the non-linear system of equations resulting from equilibrium and compatibility conditions.

This methodology is a simplified alternative to obtain the ultimate bending moment of reinforced and prestressed concrete beams that complies with the requirements of NBR 6118: 2014. A satisfactory validation was obtained for this model when compared with experimental results found in the literature.

By observing the results of Table 9, it can be noted that the model for calculation of the ultimate bending moment exposed in this work presents good results.

This tool is a great ally in the analysis of structural elements of reinforced and prestressed concrete, presenting good results and a low computer processing time.

This model will be used in the evaluation of the reliability of beams of prestressed concrete bridges.

\section{References}

[1] ANG, A. H.; TANG, W. H. Probability concepts in engineering planning and design. Volume I: basic principles. John Wiley \& Sons, 1975.

[2] ARAÚJO, J. M. Curso de concreto armado, Volume I, II, III e IV. Editora Dunas, 2014.

[3] ASSOCIAÇÃO BRASILEIRA DE NORMAS TÉCNICAS. NBR 6118: Projeto de estruturas de concreto - Procedimento. Rio de Janeiro, 2014.

[4] BILLET, D. F. Study of prestressed concrete beams failing in flexure. 1953. Thesis, University of Illinois.

[5] FELDMAN, A. Bonded and unbonded prestressed concrete beams failing in flexure. University of Illinois, 1954.

[6] MAGALHÃES, F. C. A Problemática dos Concretos NãoConformes e sua Influência na Confiabilidade de Pilares de Concreto Armado. 2014. Tese (Doutorado em Engenharia Civil) - Programa de Pós-Graduação em Engenharia Civil, Universidade Federal do Rio Grande do Sul, Porto Alegre.

[7] MAGALHÃES, F.; REAL, M. V.; SILVA FILHO, L. C. P. The problem of non-compliant and its influence on the reliability of reinforced concrete columns. Materials and structures, v. 49, p. 1485-1497, 2016.

[8] MATTOCK, A. H.; YAMAZAKI, J.; KATTULA, B. T. Comparative study of concrete prestressed beams, with and without bond. ACI Journal, February, 1971.

[9] NOWAK, A. S.; COLLINS, K. R. Reliability of Structures. MC Graw Hill, 2000.

[10] ROCHA, R. G.; REAL, M. V.; MOURA, M. W. Estudo da confiabilidade de vigas de concreto protendido. Engevista (UFF), v. 17, p. 573-587, 2015.

[11] TAO, X.; DU, G. Ultimate stress of unbonded tendons in partially prestressed concrete beams. Journal of Building Structures, December, 1985.

[12] WARWARUK, J, Strength in flexure of bonded and unbonded prestressed concrete beams. University of IIIinois, 1957. 